\title{
PIETRO ANTONIO BIANCO'S MISSA PERCUSSIT SAUL MILLE A PRECURSOR OF THE HABSBURG IMPERIAL MUSICA POLITICA OF THE SEVENTEENTH CENTURY
}

\author{
KLEMEN GRABNAR \\ Muzikološki inštitut ZRC SAZU
}

Izvleček: V prispevkuje rekonstruiran najverjetnejši okvir, v katerem lahko razumemo nastanek skladbe Missa Percussit Saul mille Pietra Antonia Bianca. Zdi se, da je leta 1601 notranjeavstrijski nadvojvoda Ferdinand II. pri svojem vodji glasbene kapele naročil mašo, osnovano na militarističnem motetu Percussit Saul mille Giovannija Croceja, in sicer za obhajanje slovesne maše pred Ferdinandovim odhodom v bitko pri Kaniži. Biancova maša se tako kaže kot glasbeni izraz političnih idej in izkazuje funkcijo, konvencijo in ideologijo, v katero je bila vpeta slovesna cerkvena glasba na graškem dvoru na prelomu v 17. stoletje. Na ta način odraža političnoglasbeno kulturo, ki je še v večji meri cvetela po tem, ko je Ferdinand postal cesar.

Ključne besede: parodična maša, Giovanni Croce, Pietro Antonio Bianco, Ferdinand II., musica politica.
Abstract: The article establishes the most appropriate context for understanding Pietro Antonio Bianco's Missa Percussit Saul mille. In 1601 the Inner-Austrian Archduke Ferdinand II appears to have commissioned a Mass based on Giovanni Croce's militaristic motet Percussit Saul mille for a solemn Mass celebrated before his departure for the battle of Kanisza. Its composition was entrusted to Ferdinand's kapellmeister, Bianco. The latter's Mass seems to be a musical statement of political ideas and demonstrates the function, convention and ideology of ceremonial sacred music at the Graz court around the turn of the sixteenth century. It reflects a political-musical culture that flourished even more greatly after Ferdinand became Emperor.

Keywords: parody Mass, Giovanni Croce, Pietro Antonio Bianco, Ferdinand II, musica politica.

As Steven Saunders has convincingly argued, there is a strong connection between the sacred music written for Ferdinand II and the politics of the period when he was Emperor. ${ }^{1}$ This connection was also very strong later on, and emerges, for instance, in Ferdinand III's patronage of sacred music, which - as has been shown by Andrew H. Weaver - can be considered as a vehicle for his monarchical representation. ${ }^{2}$ Many of the compositions written for Ferdinand and his Imperial successors contained significant musical statements

1 Saunders, "Hapsburg Court of Ferdinand II", 359-403. With some changes, this article was later incorporated in Saunders's book entitled Cross, Sword and Lyre. In both essays Saunders employs the term musica politica, which was already used in the seventeenth century: for instance, by Athanasius Kircher and Giovanni Andrea Bontempi. See also Scherliess, "Musica politica".

2 Weaver, Sacred Music as Public Image. 
of political ideas. Much less about this kind of connection is known from the preceding period, when Ferdinand was Inner-Austrian Archduke. This article therefore aims to show how sacred music began already under the patronage of Archduke Ferdinand to be employed as a tool for propagating his triumphant public image. It also endeavours to reach an understanding of how he modified this use of sacred music when he became Emperor. On the basis of a brief and tentative textual, musical and political-historical analysis it is proposed that Pietro Antonio Bianco wrote his Mass for a special occasion at which sacred music was an important aid to communicating to the public Ferdinand's image as a powerful, victorious ruler.

Following his installation as Regent in 1595 Ferdinand assumed the government of Inner Austria in 1596. Without hesitation he speedily reconstituted the Hofmusikkapelle, which had been disbanded after his father's death in 1590. Even more than his predecessor Karl, Ferdinand harboured an unmistakable inclination towards Italian musicians, appointing to the principal musical post a Venetian, Pietro Antonio Bianco (c. 1540-1611), whose predecessor, Simone Gatto (c. 1545-1594/5), had likewise been a Venetian. In order to recruit musicians Bianco was sent to Venice; he visited that city several times, and Venetian music accordingly became the most important musical influence at the Graz court. ${ }^{3}$

Two years later, in 1598, Ferdinand himself set out on a journey to Italy that would have a great impact on him, both politically and musically. ${ }^{4}$ This visit is discussed in a very informative article by Theophil Antonicek, which focuses exclusively on Ferdinand's musical experiences. Which compositions the young Archduke actually heard is not known. However, a solitary exception is the motet Percussit Saul mille by Giovanni Croce, to which he had undoubtedly listened at Santa Maria della Pietà in Venice on 1 May. Ferdinand was obviously so impressed by Croce's piece that he went to the lengths of ordering a copy of the motet for his own Kapelle. ${ }^{5}$

Giovanni Croce (c. 1557-1609) lived all his life in Venice, and served the churches of San Marco and Santa Maria Formosa. His works were very popular at the turn of the sixteenth century, a fact attested by the numerous reprints of his collections and the presence of his pieces in several anthologies. Croce's Percussit Saul mille was published in his first book of eight-voice, double-choir motets entitled Motetti a otto voci [...] comodi per le voci, e per cantar con ogni stromento, the original edition of which was published by Giacomo Vincenti in Venice in 1594. This edition went through no fewer than six reprints. ${ }^{6}$ The text, based in part on the Vulgate, is drawn from the words of the Israelite women following David's slaying of Goliath:

Percussit Saul mille,

et David decem millia,

quia manus Domini erat cum illo.

3 On the interest in Italian music at the Graz court, see Federhofer, Musikpflege und Musiker am Grazer Habsburgerhof.

4 Saunders, Cross, Sword, and Lyre, 6.

5 Antonicek, "Italienische Musikerlebnisse Ferdinands II.". The principal source of information for Antonicek was the diary of the journey kept by Ferdinand's secretary, Peter Casal.

6 The collection was reprinted in 1596, 1599, 1603, 1607, 1615 and 1622. Modern edition: Croce, First Book of Motets for Eight Voices and Organ. 


\author{
Percussit Philistaeum \\ et abstulit opprobrium ex Israel. \\ Nonne iste David \\ de quo canebat in choro dicentes: \\ percussit Saul mille, \\ et David decem millia, \\ quia manus Domini erat cum illo? ${ }^{7}$
}

A variant of the present text was used as a responsory in the Roman liturgy on the Monday after Trinity Sunday and the third Sunday after Pentecost. Richard Charteris and Michael Procter have pointed out that Croce's setting was probably regarded as an acceptable liturgical variant, although it may have been composed for extra-liturgical use. ${ }^{8}$

This composition is one of two pieces in Croce's first book of motets that are linked to more or less recent military events (the other is a Benedictus Dominus Deus Sabaoth). Martin Morell has concluded that these works were composed to celebrate either the victory at the battle of Sisak (which took place in Croatia on 22 June 1593) or the naval victory at the battle of Lepanto (this battle had taken place on 7 October 1571, which means that the work might have been written for one of its annual commemorations). ${ }^{9}$

Percussit Saul mille is a rather typical representative of Croce's livelier, or - as Anthony Carver calls it - "lighter", style, with its fanfare-like writing. It opens with concise and lively imitation leading to music in the battle idiom for "et David decem millia", represented by rapid repeated notes (see music example 1 in the appendix). ${ }^{10}$ For the most part, the motet divides into short phrases, each repeated antiphonally (there are only a few instances of minor adjustments of scoring and harmony). Because both choirs have the same cleffing, the antiphonal repetitions occur at the unison. They increasingly overlap, which is the classic constructional device of polychoral music. The function of tutti sections is to portray or emphasize a phrase of text and provide musical punctuation. Croce's tonal orbit is here rather restricted, and he may even be - as Carver has put it - "guilty of tonal monotony."

7 In English translation:

"Saul hath slain a thousand, and David ten thousand, for the hand of the Lord was with him.

He hath slain the Philistines and taken away the shame of Israel.

Is not this that David of whom the multitude sang, saying:

Saul hath slain a thousand, and David ten thousand, for the hand of the Lord was with him?"

8 Charteris and Procter, "Texts and translations", in Croce, First Book of Motets for Eight Voices and Organ, LXII.

9 Ibid., LXIII.

${ }^{10}$ Carver, Cori spezzati, 174.

${ }^{11}$ Ibid., 176. 
indeed, for Croce himself to have written a parody Mass on it. Missa Percussit Saul mille is the first of three Masses published in his 1596 collection of Messe a otto voci, being immediately, and significantly, followed by a Missa la battaglia. ${ }^{12}$ As Gernot Gruber has established, Croce's motet also served as the model for two further compositions, which are a Mass and a Magnificat by Ferdinand's Kapellmeister in Graz, Pietro Antonio Bianco. ${ }^{13}$

Bianco's Mass adheres closely to the structural principles of settings of the Ordinary of the Mass popular at the Graz court: a rather extended, tripartite Kyrie (Kyrie I, Christe, Kyrie II); a relatively compact Gloria in two sections (Et in terra, Qui tollis); a Credo in four sections, the third of which is scored for a reduced number of voices (Patrem, Et incarnatus est, Crucifixus, Et in Spiritum); a tripartite Sanctus, with the Benedictus scored for a smaller number of voices and with only one Osanna (placed at the end) in triple time (Sanctus [sine Osanna], Benedictus, Osanna); and an exceedingly brief single Agnus Dei. It is no coincidence that a fair number of Masses by Orlando di Lasso - and also by Simone Gatto, who worked in Munich for a while - adopt a similar structure. ${ }^{14}$ Bianco's Mass is rather short, possibly reflecting the brevity of the model itself. The selection of a model that projects a sense of cantus/bassus polarity inevitably conditioned Bianco's parody technique. Much of the Mass, in fact, consists of adaptations taken from all voices of the motet at their original pitch. Some sections of the Mass differ from the original only through small adjustments to the rhythm and the length of phrases necessitated by differences between the two texts. At many other points in the Mass, too, Bianco "lifted" passages from the motet with only minimal adaptation. The transposition of phrases taken from the motet is relatively rare. Phrases in the Mass almost always begin at the same pitch as the equivalent material from the model. However, a few of the Mass's phrases are rewritten so as to lead to a cadential destination different from that in the motet. But the tonal ambit expands primarily in the newly inserted portions (in fact, there are even some entirely newly composed sections - for example, the Crucifixus and Osanna). In these instances Bianco's treatment of the two bass parts is more independent than Croce's. Additionally, Croce's texture tends to be simple and very clear-cut; however, Bianco's is a little more varied. In contrast to the motet, the Mass sometimes features an alternation of the choirs where each choir adds a new idea to the discourse, while here and there an entire passage is given over to a single choir.

If we compare the Masses of Croce and Bianco, we can recognize some similar traits. Moreover, certain factors even suggest that Bianco could have been familiar with Croce's Mass. For example, Kyrie I is modelled exclusively on the introductory polyphonic music material of the model in a very similar way, besides being of exactly the same length (see music examples $2 \mathrm{a}$ and $2 \mathrm{~b}$ in the appendix). Further, the cadences ending all

${ }^{12}$ The collection was published in Venice by Giacomo Vincenti and was later reprinted four times (in 1600, 1604, 1607 and 1612). Modern edition: Croce, Messe a 8 voci.

${ }^{13}$ Gruber, "Beiträge zur Geschichte und Kompositionstechnik des Parodiemagnificat", 130. The modern edition of Bianco's Mass is available in Grabnar, Selected Works from the Hren Choirbooks, while an edition of his Magnificat is available in Gruber, Parodiemagnificat aus dem Umkreis der Grazer Hofkapelle.

${ }^{14}$ See Orlich, Die Parodiemessen von Orlando di Lasso. 
the principal sections are (with one exception) the same, and some passages even utilize the same music, as occurs, for example, at the "Deum de Deo" in the Credo (see music example 3 in the appendix). Likewise, the ending of the Gloria is strikingly similar (see music example 4 in the appendix).

Of course, there are also a fair number of differences. For example, the section for a reduced number of voices - the Crucifixus - is free in Bianco's Mass, but develops ideas from the model in Croce's. Speaking generally, there is a notable amount of fairly literal quotation in Bianco's Mass, while Croce draws on the model in a much less literal fashion. Moreover, Bianco's Mass contains both literal quotation and "free" music, while Croce's contains in addition some lengthy sections featuring a more remote derivation of material. Nevertheless, definite skill is shown in the way in which Bianco juxtaposes and joins together the various portions of the motet.

At Ferdinand's court Croce's Masses were well known. There are at least two Masses by him contained in choirbooks of Graz origin: the already mentioned Missa la battaglia and his Missa Jubilate Deo for sixteen voices. ${ }^{15}$ The question then arises: why would Bianco write a Mass on Croce's motet Percussit Saul mille if there was a Mass on the same model by Croce himself to hand? There could certainly not be any aesthetic reasons arising from a view that the second piece was of low quality, for Croce's Mass is, as Denis Arnold wrote, "a particularly splendid work, full of virile rhythms and containing harmonic asperities not unlike those of English composers of the period."16

It is known that the performance of new works was by no means the norm, and newly composed settings of the Ordinary probably constituted only a small fraction of those performed (it is significant in this respect that Bianco's opus contains only one Mass). Accordingly, new music was composed only for particularly festive occasions. It would therefore appear that Bianco's Mass arose from some sort of a commission for a very special occasion. But what would that occasion have been, and when would it have occurred?

Without doubt, the Mass was written between 1598, by which time both the model and the Mass by Croce were published, and 1611, the year of Bianco's death. Since the text of the model was unmistakably associated with a battle, the Mass, too, must have been written for a battle commemoration or something similar. ${ }^{17}$ Because this is a unique instance of such a commission of which we have knowledge, this occasion must have possessed especial gravitas. One such instance stands out. This occurred at St. Aegidius in Graz on 23 August 1601 and would fit the circumstances perfectly. It was a solemn

15 The first is contained in one of the Hren choirbooks (SI-Lnr, Ms 339), while the second is preserved in Vienna (A-Wn, Ms 16702).

16 Arnold, "Croce, Giovanni", 711.

17 There is a whole series of compositions descriptive of, or linked in one or another way, to battles in sixteenth-century music. The most celebrated and influential of this kind of pieces was the chanson La guerre by Clément Janequin (also known as La bataille or Escoutez tous gentilz), which commemorates the victory of François I of France over the forces of Duke Ercole Sforza of Milan at the Battle of Marignano in 1515. The above-mentioned Missa la battaglia by Croce is one of several parody Masses modelled on Janequin's chanson. See Croce, Messe a 8 voci. More on some of the other parody Masses of this kind, see for instance Gudmundson, "Parody and Symbolism in Three Battle Masses". 
Mass celebrated before Ferdinand's departure for Kanisza in Lower Hungary, where he personally led his soldiers into battle against the Turks. As Robert Bireley writes, after the Mass "the nuncio presented Ferdinand with a banner, and prayers were ordered to be said in all the churches of Inner Austria throughout the campaign." 18 As things turned out, the operation proved a disaster. Because of the swampy terrain, cold, snow and a sharp wind, the army withdrew. Bireley records that "[s]ix thousand wounded and sick were left on the battlefield, to be subsequently beheaded by the Turks". ${ }^{19}$ In the absence of any other prominent occasions of similar type and taking other circumstantial evidence into account, it seems fairly certainly that the Mass dates from 1601.

It must be said that there is a more profound reason why Ferdinand was so enthusiastic about Croce's militaristic motet with its unmistakable overtones of victory over enemies and perhaps required Bianco to compose a Mass based on it for this particular occasion in the political-religious life of the Inner-Austrian court: like King David, to whom Ferdinand compared himself, he trusted in God to defend him from all his enemies, the foremost of whom were the Turks. ${ }^{20}$ As Ferdinand was also a major proponent of the Counter-Reformation in Inner-Austria, Bianco's Mass must have been in the same time perceived by (at least some of the) contemporary listeners as a strongly anti-Protestant statement. The function of this kind of music was thus not merely a courtly representation but also a demonstration of the authority and majesty of the ruler. The Mass must certainly have pleased the Archduke - an outcome also suggested by the high incidence of quoted or paraphrased material taken from the model.

The Mass is thus a significant musical legacy of Ferdinand's Italian journey, one that could be seen as an addition to the Italian musical souvenirs collected elsewhere in a choirbook today held by the Österreichische Nationalbibliothek in Vienna. ${ }^{21}$ The works it contains are by Croce, both Andrea and Giovanni Gabrieli and other Italian composers. After Ferdinand became Emperor this manuscript was transferred from Graz to Vienna. It is interesting that at least three of its motets served as models for parody Masses by composers working in Ferdinand's Hofmusikkapelle: Bianco employed Croce's motet Percussit Saul mille; Georg Poss, Giovanni Gabrieli's motet Hoc tegitur; and Giovanni Valentini, another motet by Gabrieli, Diligam te Domine. ${ }^{22}$ This is clear evidence that these motets were highly appreciated by Fedinand.

Although Ferdinand took his most admired music with him to Vienna - Croce's Percussit Saul mille included - Bianco's Mass seems not to have formed part of the relocated repertoire. Perhaps there was some bitterness attached to the Mass, brought about by the fact that in 1601, at Kanisza, the Emperor had been forced to retreat. It seems Ferdinand realized it is better to celebrate a festive Mass in this vein only after

${ }^{18}$ Bireley, Ferdinand II, 43.

${ }^{19}$ Ibid., 44.

${ }^{20}$ Ibid., 37.

${ }^{21}$ A-Wn, Ms 16703.

${ }^{22}$ Annibale Perini's Mass based on the motet Benedicite omnia opera Domini by Ruggiero Giovannelli should most probably also be regarded as one of these parody compositions. Grabnar, Selected Works from the Hren Choirbooks, XXVI-XXVIII. 
the military success has been assured, as indicated for instance by Giovanni Valentini's seven-choir Jubilate Deo. ${ }^{23}$

Bianco's Mass can be seen as an example of the function, convention and ideology of music in Graz court ceremonies. At Ferdinand's court in Graz sacred compositions were already showing an increasingly militant expression. Bianco's Mass (like his Magnificat) provides clear illustrations of these tendencies. It therefore represents a fine example of musica politica, a political-musical culture that is traceable already from Ferdinand's Graz years when he was Inner-Austrian Archduke but flourished even more greatly after he became Emperor.

\section{Appendix}

\section{Music example 1}

Giovanni Croce, Percussit Saul mille, beginning

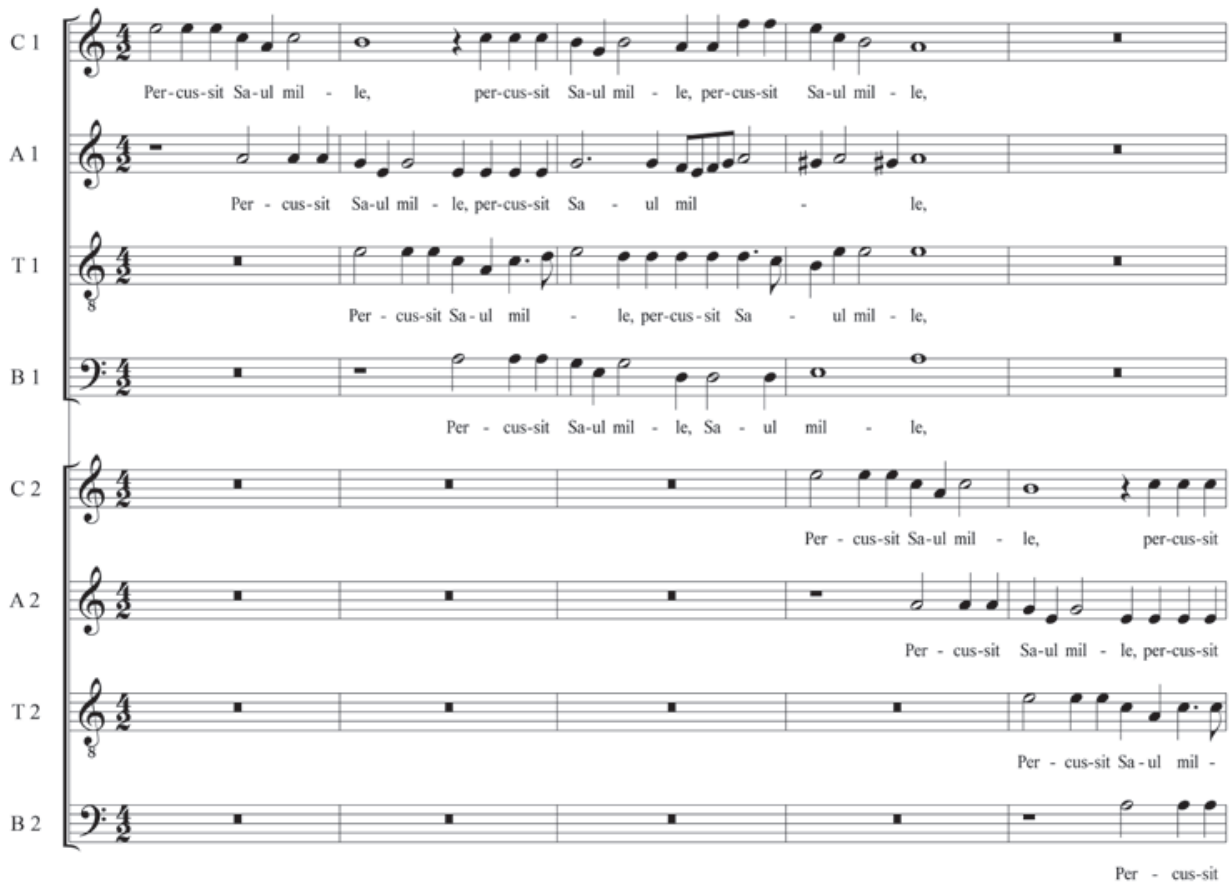

${ }^{23}$ Saunders, Cross, Sword, and Lyre, 105-106. 


\section{Music example 1}

(continued)

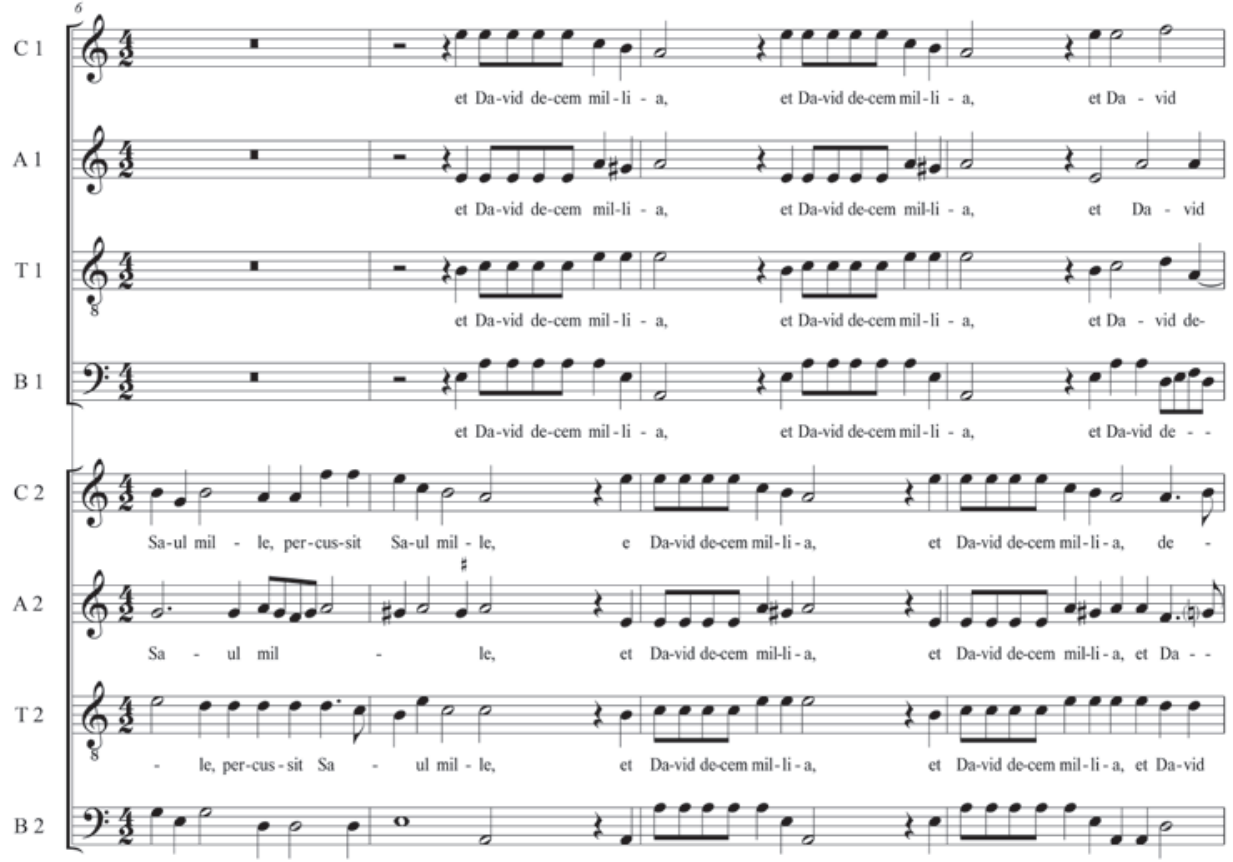
Sa-ul mil
le, Sa - ul mil - le,
et Da-vid decem mil-li-a,
et Da-vid de-cem mil-li-a, et Da- 


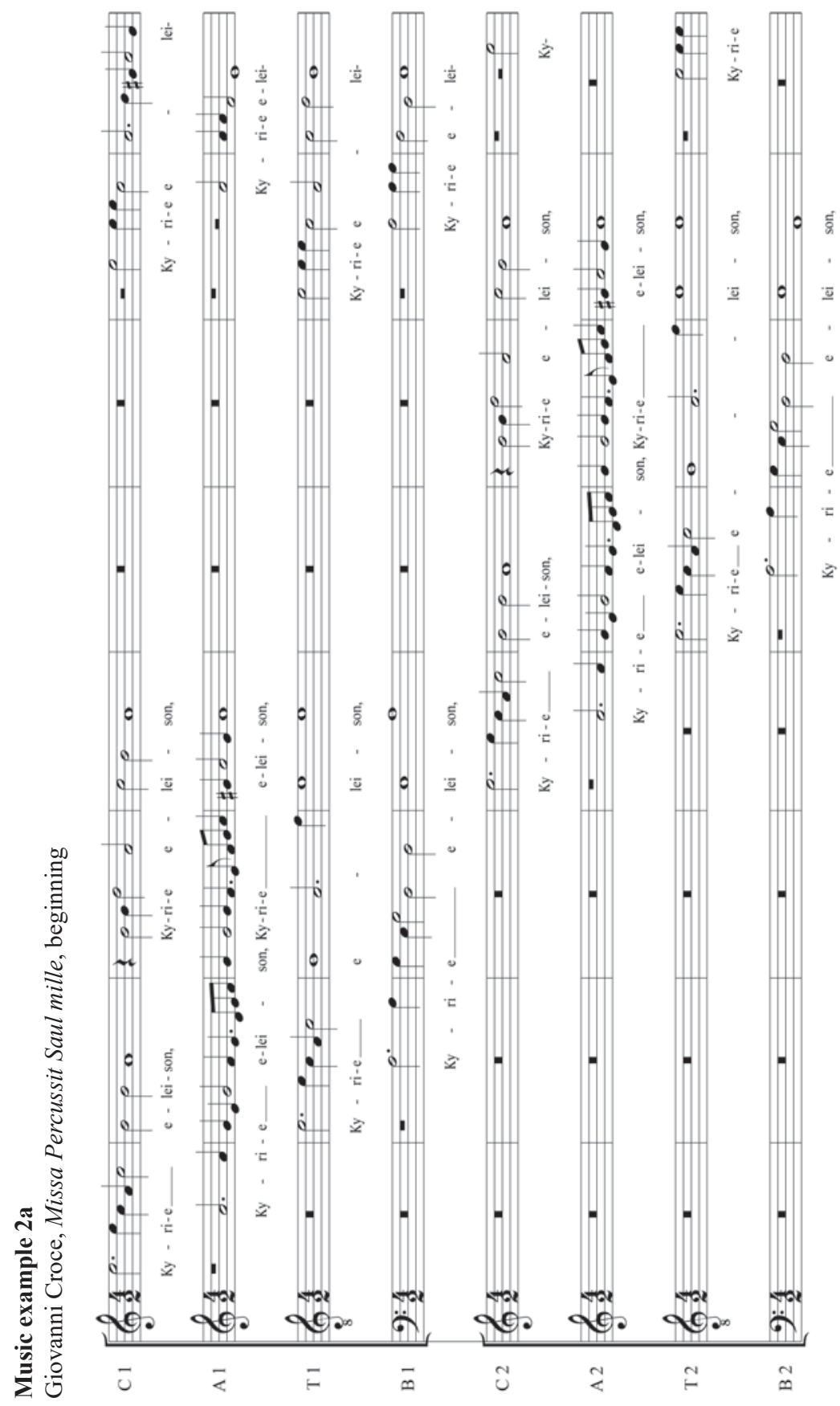




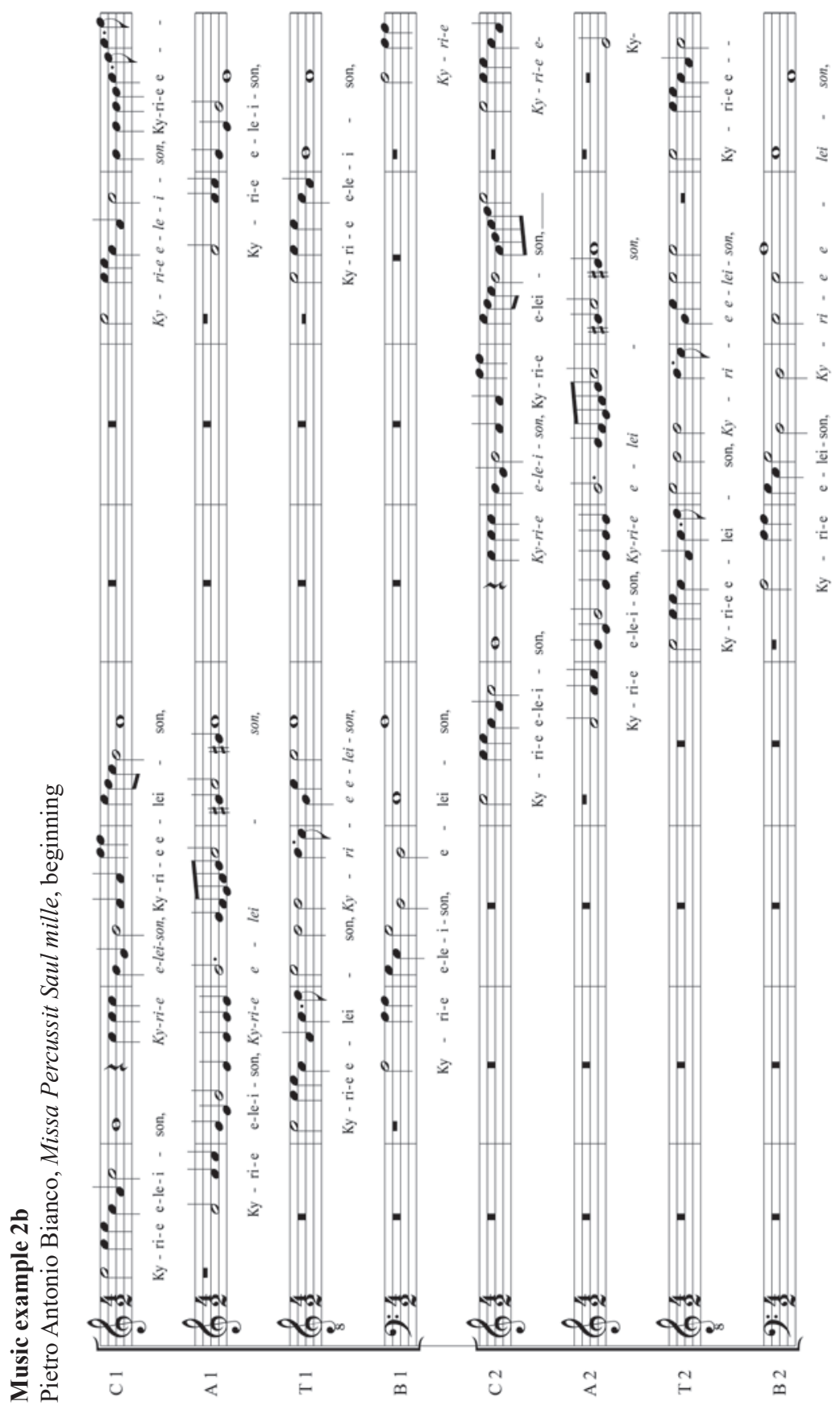




\section{Music example 3}

Left, Giovanni Croce, Missa Percussit Saul mille, Credo (excerpt)

Right, Pietro Antonio Bianco, Missa Percussit Saul mille, Credo (excerpt)
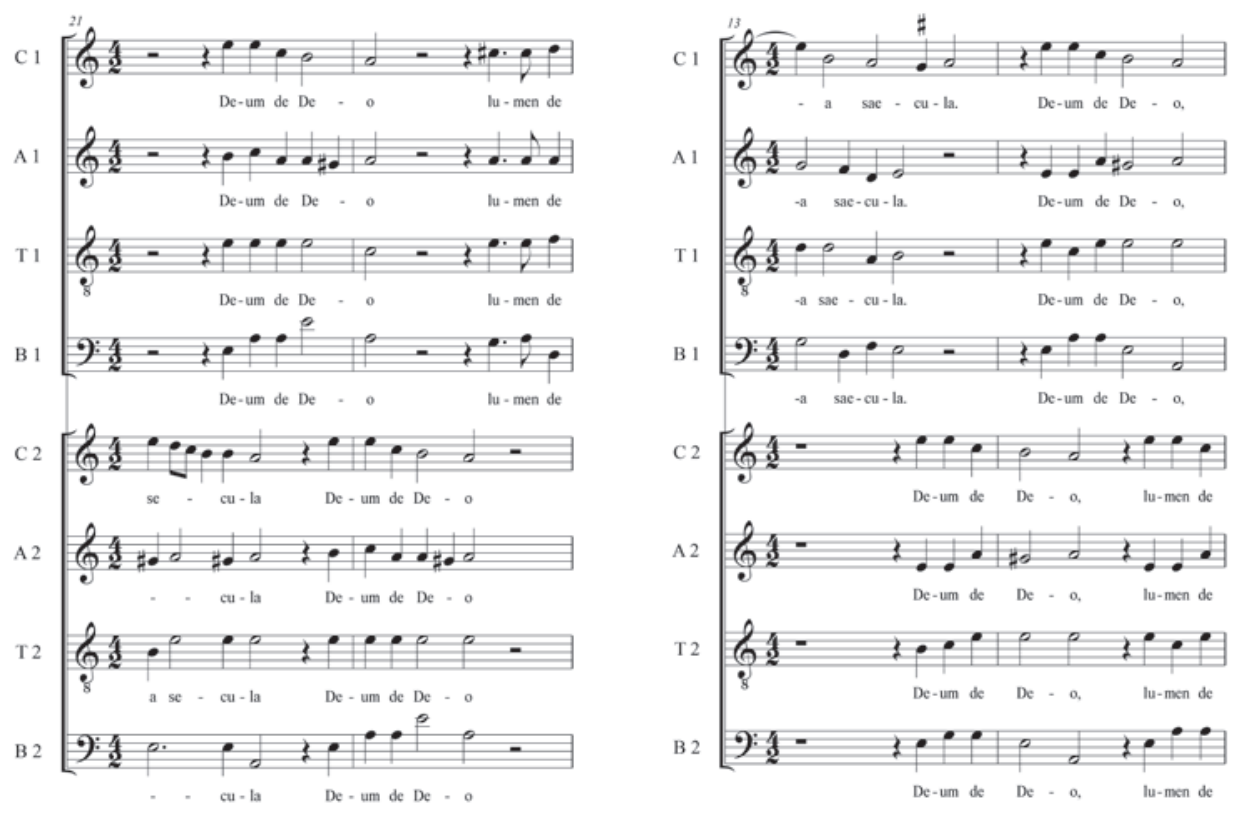


\section{Music example 4}

Left, Giovanni Croce, Missa Percussit Saul mille, Gloria (ending)

Right, Pietro Antonio Bianco, Missa Percussit Saul mille, Gloria (ending)
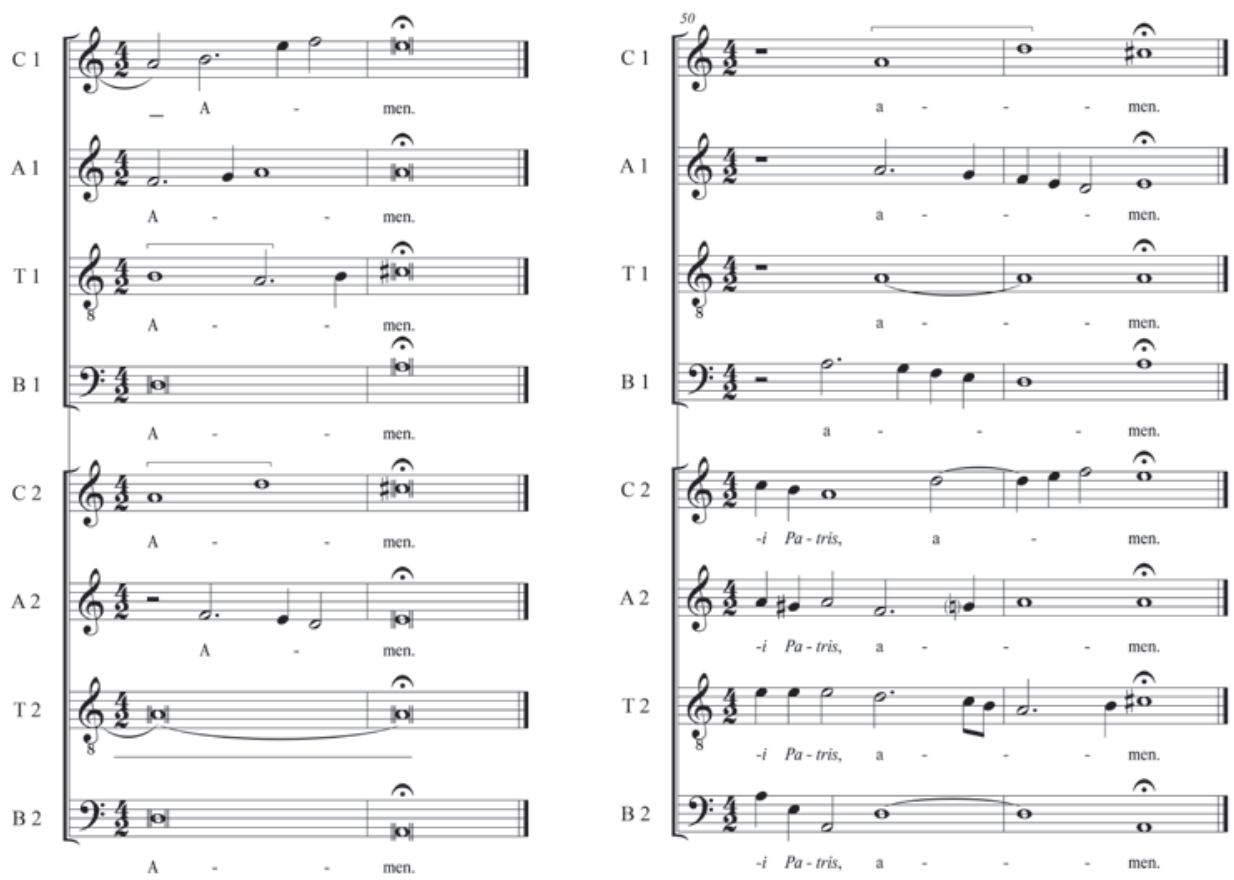

\section{Sources and Literature}

\section{MANUSCRIPT SOURCES}

Ljubljana, Narodna in univerzitetna knjižnica, Zbirka rokopisov, redkih in starih tiskov (SI-Lnr), Mss 339 and 341.

Vienna, Österreichische Nationalbibliothek, Musiksammlung (A-Wn), Mss 16702 and 16703.

\section{LITERATURE}

Antonicek, Theophil. "Italienische Musikerlebnisse Ferdinands II. 1598”. Anzeiger der Österreichischen Akademie der Wissenschaften, philosophisch-historische Klasse 104 (1967): 91-111.

Arnold, Denis. “Croce, Giovanni”. In The New Grove Dictionary of Music and Musicians. 2nd ed., edited by Stanley Sadie (London: Macmillan, 2001), 6:711.

Bireley, Robert. Ferdinand II, Counter-Reformation Emperor, 1578-1637. New York: Cambridge University Press, 2014. https://doi.org/10.1093/ahr/120.5.1992.

Carver, Anthony. Cori spezzati. Vol. 1, The Development of Sacred Polychoral Music to the Time of Schütz. Cambridge: Cambridge University Press, 1988. 
Croce, Giovanni. First book of Motets for Eight Voices and Organ. Edited by Richard Charteris with the assistance of Michael Procter. Hillsdale, NY: Pendragon Press, 2014.

___ Messe a 8 voci, 1596. Edited by Michael Procter. Quatercentenary Edition of the sacred music of Giovanni Croce, 2. Weingarten: Edition Michael Procter, 2009.

Federhofer, Hellmut. Musikpflege und Musiker am Grazer Habsburgerhof der Erzherzöge Karl und Ferdinand von Innerösterreich (1564-1619). Mainz: B. Schott's Söhne, 1967.

Grabnar, Klemen, ed. Izbrana dela iz Hrenovih kornih knjig/Selected Works from the Hren Choirbooks. Vol. 1, Annibale Perini, Missa Benedicite omnia opera Domini \& Pietro Antonio Bianco, Missa Percussit Saul mille. Monumenta artis musicae Sloveniae, 62. Ljubljana: Založba ZRC, ZRC SAZU, 2017.

Gruber, Gernot. "Beiträge zur Geschichte und Kompositionstechnik des Parodiemagnificat in der 2. Hälfte des 16. Jahrhunderts". PhD diss., Karl-Franzens-Universität in Graz, 1964.

—_- ed. Parodiemagnificat aus dem Umkreis der Grazer Hofkapelle (1564-1619). Denkmäler der Tonkunst in Österreich, 133. Graz: Akademische Druck- u. Verlagsanstalt, 1981.

Gudmundson, Harry Edwin. "Parody and Symbolism in Three Battle Masses of the Sixteenth Century”. PhD diss., University of Michigan, 1976.

Orlich, Rufina. Die Parodiemessen von Orlando di Lasso. Münchner Universitäts-Schriften, Philosophische Fakultät: Studien zur Musik, 4. Munich: Wilhelm Fink Verlag, 1985.

Saunders, Steven. Cross, Sword and Lyre: Sacred Music at the Imperial Court of Ferdinand II of Habsburg (1619-1637). Oxford: Clarendon Press, 1995.

___ _ " "The Hapsburg Court of Ferdinand II and the Messa, Magnificat et Iubilate Deo a sette chori concertati con le trombe (1621) of Giovanni Valentini". Journal of the American Musicological Society 44 (Autumn 1991): 359-403. https://doi. org/10.2307/831644.

Scherliess, Volker. "Musica politica”. In Festschrift Georg von Dadelsen zum 60. Geburtstag, edited by Thomas Kohlhase and Volker Scherliess, 270-283. Neuhausen, Stuttgart: Hänssler-Verlag, 1978.

Weaver, Andrew H. Sacred Music as Public Image for Holy Roman Emperor Ferdinand III: Representing the Counter-Reformation Monarch at the End of the Thirty Years' War. Catholic Christendom, 1300-1700. Farnham, Surrey, UK: Ashgate, 2012. https://doi. org/10.4324/9781315607351. 


\section{MISSA PERCUSSIT SAUL MILLE PIETRA ANTONIA BIANCA ZNANILKA HABSBURŠKE CESARSKE MUSICAE POLITICAE SEDEMNAJSTEGA STOLETJA}

\section{Povzetek}

Leta 1598 se je notranjeavstrijski nadvojvoda Ferdinand II. odpravil v Italijo na potovanje, ki je pomembno vplivalo na njegovo politiko in na njegov pogled na glasbo. Katere skladbe je mladi nadvojvoda tam poslušal, ni znano, z izjemo moteta Percussit Saul mille Giovannija Croceja. Ferdinand je bil nad motetom tako navdušen, da je za svojo kapelo naročil prepis te skladbe. Croce sam je na osnovi svojega moteta oblikoval mašo, njegov motet pa je služil tudi kot predloga maši in magnifikatu Ferdinandovega vodje kapele v Gradcu, Pietra Antonia Bianca (ok. 1540-1611). Če med seboj primerjamo Crocejevo in Biancovo mašo, lahko prepoznamo nekatere skupne značilnosti. Posamezni elementi celo nakazujejo, da je Bianco poznal Crocejevo mašo. Tako se postavlja vprašanje, zakaj bi Bianco napisal mašo na osnovi Crocejevega moteta Percussit Saul mille, če je bila maša, ki temelji na istem modelu in izpod peresa Croceja samega, že pri roki. Znano je, da je bilo izvajanje novih del redko in da so nove uglasbitve besedil mašnega ordinarija predstavljale le majhen delež vseh izvajanih maš. Nova glasba je bila torej zložena le za posebne slavnosti. Zato se na podlagi okoliščin zdi, da je bila Biancova maša plod naročila za posebno priložnost, in sicer za slovesno mašo - darovano 23. avgusta 1601 v cerkvi sv. Egidija v Gradcu - pred odhodom Ferdinanda v bitko na Madžarsko (Kaniža), v kateri je Ferdinand osebno vodil vojsko v boj s Turki. Zaradi ujemajočih se okoliščin in dejstva, da kakšen drug primerljivo pomemben dogodek ni znan, se zdi tako zelo verjetno, da je Bianco mašo napisal leta 1601. Njegovo mašo lahko vidimo kot primer ideologije in funkcije, ki jo je imela glasba pri slovesnostih na graškem dvoru; že na Ferdinandovem graškem dvoru je sakralna glasba izkazovala militanten izraz. Biancova maša tako predstavlja primer musicae politicae, politično-glasbene kulture, ki je še v večji meri cvetela potem, ko je Ferdinand postal cesar. 